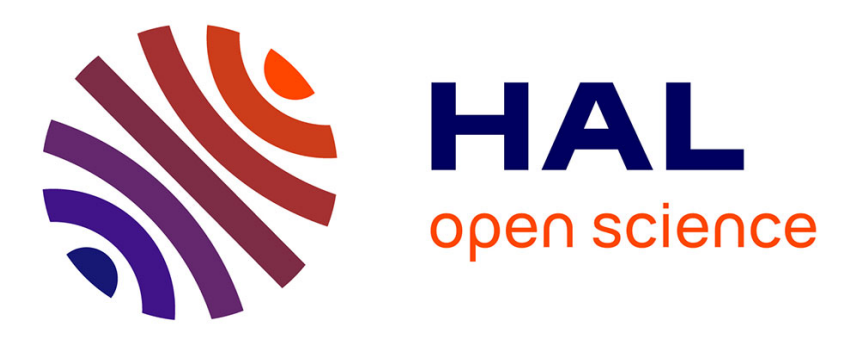

\title{
The path of innovation: purchasing and supplier involvement into new product development
}

Davide Luzzini, Markus Amann, Federico Caniato, Michael Essig, Stefano

Ronchi

\section{- To cite this version:}

Davide Luzzini, Markus Amann, Federico Caniato, Michael Essig, Stefano Ronchi. The path of innovation: purchasing and supplier involvement into new product development. Industrial Marketing Management, 2015, 47, pp.109-120. 10.1016/j.indmarman.2015.02.034 . hal-01289738

\section{HAL Id: hal-01289738}

https://hal-audencia.archives-ouvertes.fr/hal-01289738

Submitted on 17 Mar 2016

HAL is a multi-disciplinary open access archive for the deposit and dissemination of scientific research documents, whether they are published or not. The documents may come from teaching and research institutions in France or abroad, or from public or private research centers.
L'archive ouverte pluridisciplinaire $\mathbf{H A L}$, est destinée au dépôt et à la diffusion de documents scientifiques de niveau recherche, publiés ou non, émanant des établissements d'enseignement et de recherche français ou étrangers, des laboratoires publics ou privés. 


\section{The path of innovation: purchasing and supplier involvement into new product development}

Authors: Luzzini, Amann, Caniato, Essig, Ronchi

Journal: Industrial Marketing Management

Link to final version:

http://www.sciencedirect.com/science/article/pii/S0019850115000693 


\title{
The path of innovation: \\ purchasing and supplier involvement into new product development
}

\begin{abstract}
This paper aims to investigate the effects of supplier collaboration on the firm innovation performance as well as the enabling characteristics of the purchasing function. This is an original contribution as few papers empirically test the effect of supplier collaboration (meant as supplier involvement, development, and integration) on innovation performance and simultaneously - the contribution of strategic sourcing activities and purchasing knowledge. Also, we explore the technological uncertainty of the purchase as an important contingent factor that might influence the firm's innovation strategy and the emphasis on supplier collaboration or strategic sourcing.

Towards this end, we develop a theoretical framework and test it through a survey conducted on a sample of 498 companies worldwide. Results show that innovation, as a category priority, does lead to emphasize supplier collaboration and strategic sourcing which, in turn, ensure better innovation performance. Empirical evidence also shows that, on the one hand, adequate purchasing (managers) knowledge enables greater supplier collaboration and strategic sourcing; on the other hand, technological uncertainty put greater emphasis on innovation strategy as well as on strategic sourcing.
\end{abstract}

Keywords: innovation; supplier collaboration; strategic sourcing; purchasing knowledge; technological uncertainty. 


\section{Introduction}

"[C]ompanies rarely innovate by themselves" (Edquist, 1997): innovation is the product of a network rather than of a single person or firm. As a matter of fact, the open and collaborative innovation paradigm represent a way to support the innovation effort by accessing external resources (e.g., knowledge, technology, human workforce) that the focal firm might lack (Chesbrough \& Crowther, 2006; Verganti, 2008). This study focuses on new product development (NPD) capabilities, which is one of the facets of innovation ${ }^{1}$.

In this context, supplier and - later - purchasing department involvement into innovation processes has been recognized as a potential source of sustainable competitive advantage, even though the literature is not fully consistent. Among external sources of innovation, suppliers have a crucial role in improving firms' innovation performance (e.g., Clark, 1989; Handfield et al., 1999): they know their customers' business and mechanisms for knowledge transfer from supplier to customer are typically in place (Yu, 2008). Suppliers' contribution assumes various forms, such as supply of innovative components and product/process technologies (Walter, 2003), or joint product development projects (Bonaccorsi \& Lipparini, 1994). Earlier and more extensive supplier involvement emerged as one of the most effective ways to improve NPD process performance (Clark, 1989; Ragatz et al., 2002). However, engaging suppliers into collaborative innovation is not so easy to achieve (Krause, 1999; Smals \& Smits, 2012). Firstly, the availability of highly-skilled suppliers is not sufficient per se: both buyer and supplier must be willing to participate into shared NPD projects and possess the necessary experience and capabilities to do so (Monczka et al., 2000; Schiele, 2006). Secondly, the interest in the subject by an increasing number of firms, the concentration of supply markets, the increasing outsourcing/offshoring rate are shifting the bargaining power from buyers to suppliers, who become highly selective and resistant to adapt to customers' requests (Christiansen \& Maltz, 2002). In order to have access to the best resources, such as brainpower, the customer must increase its level of attractiveness (Schiele et al., 2011). Firms' top management is therefore dedicating more resources to engage suppliers beyond traditional power-dominated relations (Cox, 1999) and to enhance their knowledge of supply markets as well as capabilities of scouting appropriate suppliers, i.e., suppliers with the right skills (Modi \& Mabert, 2007).

A naturally consequent stage of research investigates what role the purchasing department plays in innovation, as it has become the common interface with the supply base (Ellram \& Pearson, 1993; Araujo et al. 1999). Firms increasingly recognize a strategic role to the purchasing department, which manages firm's expenditures (normally accounting for more than $50 \%$ of the firm's turnover) together with internal customer departments. Therefore, today the goals of the purchasing department go well beyond savings and costs reduction. While standard and easy-to-find purchasing categories does require costs minimization, critical categories emphasize other competitive priorities, such as quality, flexibility, and innovation (Luzzini et al., 2012).

Although the literature recognizes that the purchasing department might represent a critical cornerstone for adapting innovation from suppliers and stewarding it through the product lifecycle, a broad empirical analysis of supplier and purchasing involvement on the innovation performance is still missing. So far, the literature focuses on adequate organizational setting (McGinnis \& Vallopra, 1999a), production process development / improvement (McGinnis \& Vallopra, 1999b), or the influence on organizational financial

\footnotetext{
${ }^{1}$ For an exhaustive review of different meanings of innovation and innovativeness the reader might refer to Garcia \& Calantone (2002).
} 
performance (Carr \& Pearson, 2002). Table 1 summarizes the (chrono)logical trend in the literature described above that lead to emphasize our perspective about NPD.

Complementary to the majority of existing research, this study investigates the antecedents of purchased products and services innovation considering both supplier and purchasing related factors as well as their mutual relations. We consider the supplier's role by including supplier collaboration as a key variable to achieve innovation, whereas the purchasing's role is modelled through strategic sourcing. We also theorize that purchasing knowledge is key to make the most of the firm's supply base as it facilitates both supplier collaboration and strategic sourcing efforts. Moreover, we consider the firm's innovation strategy as an important enabler of supplier collaboration and strategic sourcing. We test our theoretical model by means of structure equation modelling using data collected with a survey of 498 international firms.

In the next section the theoretical background and research hypotheses are explained, followed by the research method (i.e., the survey and measures used). The last three sections present data analysis, discuss results, and summarize main conclusions respectively.

Insert Table1 here

\section{Theoretical background}

Compared to the widespread literature on supplier involvement and its potential benefit on the NPD process, relatively smaller and more recent attention has been paid to the role of the purchasing department, which is increasingly taking the lead in the management of supply relationship. It is still not clear whether or not the purchasing department significantly contributes to the innovation outcomes (Mendez \& Pearson, 1994); more specifically, we wonder whether or not purchasing professionals' knowledge facilitate the process of supplier involvement and therefore the firm capability to innovate.

CAPS research (2011) emphasizes the relevance of supply network relationships as a mean to speed up innovation ideas to commercialization. The proposed set of main supply strategies contains the crucial aspects addressed by this study: robust category strategy development and execution; early supplier involvement in new product development; supplier relationship management with a focus on trust building and communication to develop preferred customer status and first access to supplier innovations; supply base management to assure access to a "bookshelf" of key suppliers with leading innovation capabilities; equitable contracting and risk/reward approaches; systems and processes to acquire, evaluate and implement supplier innovations.

Our theoretical framework grounds on the Resource Based View of the firm (RBV) and some related perspectives such as the extended RBV, Dynamic Capabilities, and the Knowledge Base View (KBV). RBV suggests that possessing resources that are rare, inimitable and non-substitutable can lead to competitive advantage and better performance (Barney, 1986, 1991). This kind of resources is commonly owned by a firm but can also be acquired from suppliers. Furthermore, they might be physical assets but also knowledge and capabilities of people working inside the firm. However, according to Day and Wensley (1988), not only does a firm need to attain superior resources but it also needs to convert those resources into positional advantages (such as cost reduction, faster delivery, or higher innovation). Positional advantages offer value added benefits that customers would pay a price premium to obtain, and thus enable a firm to achieve superior performance (Song et al., 2011). 
Innovation can be considered a positional advantage and is precursor of success (Chen et al., 2010; Henard \& Szymanski, 2001; Song and Parry, 1999; Swink \& Song, 2007; Song et al., 2011). We therefore focus on two possible antecedents (i.e., sources of advantage): supplier collaboration and strategic sourcing, which are in line with the RBV and the above mentioned derivatives (e.g. Ramsay, 2001). Also, we argue that possessing compelling purchasing knowledge is an important enabler of both sources of advantage. In our view, the skills and competences of purchasing managers only influence innovation outcomes in an indirect way through the collaboration with suppliers and strategic sourcing related to NPD. Finally, we include innovation strategy as the factor leading to look for specific sources of advantage. The resulting theoretical model is shown in Figure 1.

\subsection{Effect of innovation strategy on supplier collaboration and strategic sourcing}

When innovation is considered a competitive priority, it is expected to be transferred from business to purchasing and ultimately to the category level, leading to emphasize supply management in order to improve component innovation rate and time-to-market (Bidault et al., 1998). The design of this strategic fit is a key element of dynamic capabilities in terms of sensing, seizing and reconfiguring supply resources in dependence to specific business environments (Teece, 2010).

As for the practices that follow an innovation strategy, Van Echtelt et al. (2008) suggest that "the process of selecting the suppliers and determining their extent of involvement are critical in anticipating and addressing the technical and organizational risks associated with particular choices about suppliers and workload outsourcing".

The authors propose to distinguish between an operational, project-related, short-term setting and a strategic, long-term-oriented setting. The former setting represents the engine to effectively set up and manage joint buyer-supplier development projects and include several processes, such as coordinating development activities with suppliers, feeding back supplier performance, or designing communication interface with suppliers. The latter setting reflects the planning, execution, and evaluative stages in developing policies and the desired supplier base. Activities included are, for instance, monitoring supply markets, pre-selecting suppliers for NPD, and periodically evaluating guidelines and supply base performance. Both sets of processes, implemented as permanent activities, can contribute to improved collaboration results. We might therefore link the company orientation to innovation to two main processes characterizing the purchasing activity (i.e, strategic sourcing and supplier collaboration) as they are determinants of NPD outcomes. Strategic sourcing includes processes associated to the strategic setting, whereas supplier collaboration reflects the operational setting.

Most of the literature is consistent with this view. As for strategic sourcing, authors generally consider purchasing integration in product development as equivalent to managing supplier involvement in new product development projects. However, further attention should be paid to long-term strategic issues, such as supply market analysis, definition of the sourcing strategy, and supplier selection (Wynstra et al., 2003). So, a wider set of purchasingrelated processes and capabilities should be considered by firms willing to foster innovation (Carr \& Pearson 2002; van Echtelt et al. 2008; Lakemond et al., 2001, Wynstra et al., 1999). This view is also backed up by the increasing attention to strategic purchasing as a powerful determinant of the firm overall performance (e.g. Chen et al., 2004; Hartman et al., 2012). Therefore, we expect that:

H1a. A higher emphasis on innovation strategy positively influences the effort on strategic sourcing.

As for supplier collaboration, a wide body of literature acknowledge the need to collaborate with suppliers when innovation is at stake (see Table 1). Indeed, suppliers own 
relevant and complementary knowledge to the buying firm's; they know the customer's internal processes and products, especially in the case of long-term relationships; they possess specific assets and resources. Through this, during the NPD phase, suppliers are able to anticipate constraints that might cause problems during the production phase, to speed up the development activities, to reduce development costs, and to improve the output quality, for the benefit of both parties. Therefore, we expect that:

\section{H1b. A higher emphasis on innovation strategy positively influences the effort on supplier collaboration.}

\subsection{Effect of purchasing knowledge on supplier collaboration}

Scholars representing the extended RBV argue that competitive advantage is derived from both internal and external assets (Squire et al. 2009). More specifically, authors suggest that external integration requires specific internal capabilities (Koufteros et al., 2005). In particular, some studies shed light on the role of the purchasing department in managing supplier involvement and the conditions enabling its effective involvement in product development (Anklesaria \& Burt, 1987; Atuahene-Gima, 1995; Dowlatshahi, 1992; van Echtelt et al., 2008). Among other organizational units, the purchasing department often takes the role of relationship manager (Dowlatshahi, 1992) and participate to supplier involvement in NPD (Bonaccorsi, 1992; Hakansson \& Eriksson, 1993; Wognum et al., 2002). On the one hand, Lakemond et al. (2001) define different configurations for purchasing integration into NPD. On the other hand, some authors investigate the role of purchasing for effective supplier integration (Wynstra et al., 2003; Wagner, 2003; McGinnis \&Vallopra, 2001; Schiele, 2010).

Few authors (e.g., Atuahene-Gima, 1995; Nijssen et al., 2002) study driving factors such as the skills of buyers and top management commitment. As suppliers are increasing their importance for manufacturers due to the increasing incidence of purchases (Roberts 2001), purchasing capabilities become crucial (Gadde \& Håkansson, 1994; Macbeth, 1994), especially in the context of NPD collaborations (Anderson \& Dekker, 2005). According to Wynstra et al. (1999, 2001), successful supplier integration is ensured by the organization of the purchasing department and adequately skilled human resources. Similarly, other authors conclude that the likelihood of supplier involved at early stages of NPD increases when purchasing professionals have a good recognition by top management (Hillebrand \& Biemans, 2004), are part of the development team (Tracey, 2006), and participate to strategic planning processes (Schiele, 2010). However, a function's role is strictly connected to the level of knowledge and skills owned by its human resources which is again in line with the KBV (Grant, 1996; Jackson et al., 2003; Youndt et al., 1996).

In summary, we expect that the more buyers are competent, specialized, and skilful, the more they will contribute to the NPD process by helping firms to successfully involve suppliers (Wynstra et al., 2001; Wynstra et al., 1999; Schiele, 2006). Although NPD projects have unique outputs, NPD activities represent an iterative process and firms can build capabilities in this regard. In particular, a connection between supplier involvement and purchasing human resource's skills and know-how should be plausible: skilled purchasing professionals are more likely to be involved in the development team and to support coordination with other partners. Therefore we state the following hypothesis:

H2. A higher level of purchasing knowledge positively influences the effort on supplier collaboration. 


\subsection{Effect of purchasing knowledge on strategic sourcing}

Since the early definitions of strategic purchasing (e.g. Ellram and Carr, 1994; Carr and Smeltzer, 1997), the literature clearly suggests the possibility for the purchasing department to improve the firm's success by actively managing the supply base and by acting as an equal partner with other peer departments. However, this is not the case for any firm. The chance to leverage purchasing as a strategic weapon significantly rests on the capabilities of the purchasing department personnel (Reck and Long, 1988). Indeed, purchasing knowledge and skills are required for purchasing to effectively perform as a strategic function (Rajagopal and Bernard, 1993). For example, strategic purchasing functions are expected to have knowledge of their external supplier environment, knowledge of their internal customer's environment, and knowledge of the firm's strategic goals. Necessary skills include analytical skills, communication skills, and general management skills (Keough, 1994; Van Weele, 1984).

As a consequence, in our study, we assume that knowledgeable and mature purchasing professionals are likely to invest a greater portion of their time in strategic activities (such as market scouting and contracting) rather than operational and administrative ones (such as order emission and payment) (Chen et al., 2004). Monitoring the supply market and constantly scouting for new sources of innovation is strictly dependent upon the availability of suitable knowledge and skills within the purchasing department. As a matter of fact, inexperienced and unskilled buyers are expected to take care of clerical rather than highly value adding activities (Cousins \& Spekman, 2003). We are therefore expecting that:

\section{H3. A higher level of purchasing knowledge positively influences the effort on strategic sourcing.}

\subsection{Effect of supplier collaboration on innovation performance}

The literature largely confirms that companies increasingly rely on their supply base to achieve innovation (Inemek \& Matthyssens, 2012; Chen et al., 2010; Koufteros \& Marcoulides, 2006; Petersen et al., 2005; Primo \& Amundson, 2002). These studies, however, mainly regard large firms and provide mixed results. It is known, for instance, that failure rates in NPD might even approach 80 percent (Cooper, 1999). This is worrisome, given that a large share of firm value comes from newly developed products or services (Mahajan \& Wind, 1991; Dowlatshahi, 1998; Birou \& Fawcett, 1994). Considering the increasing outsourcing rate (Quinn \& Hilmer, 1994), it is not surprising that research on supplier collaboration has greatly expanded during the last 30 years. In particular, scholars have been focusing on different facets of collaborations, including supplier involvement in NPD, supplier development, and supplier integration.

Supplier involvement in NPD concerns the integration of suppliers' capabilities into NPD projects (Dowlatshahi, 1998), the tasks they are able to carry out on behalf of the customer, and the responsibilities they assume for the development of a part, process or service (van Echtelt et al., 2008). On the one hand, supplier involvement potentially results in lower costs, higher quality, faster NPD time, and so on (see for instance Clark, 1989; Ragatz et al., 2002; Petersen et al., 2003; Wagner \& Hoegl, 2006). On the other hand, longer development times and increased costs (Ragatz et al., 1997) as well as dissatisfaction with NPD outcomes (Handfield et al., 1999) might occur.

Supplier development involves a short-term sacrifice by the buying firm and the supplier; both firms must allocate resources and personnel time to the effort. Supplier development is defined as the set of activities undertaken by the buying firms in their efforts to measure and improve the products or services they receive from their suppliers and is associated to supplier performance improvement (Prahinski \& Benton, 2004). 
Finally, we know that the NPD process can benefit from supplier integration, that is the extent to which a firm is strategically interconnected and aligned with its supply chain partners (Das et al., 2006; Jayaram et al., 2010). Multiple studies associate the supplier integration with increased performance (e.g., Frohlich \& Westbrook, 2001; Ragatz et al., 2002; Braunscheidel \& Suresh, 2009; Flynn et al., 2010; Wong et al., 2011; Zhao et al., 2011). In general, scholars argue that benefits of integration outweigh its associated costs, leading to greater operational performance (Primo \& Amundson, 2002; Koufteros et al., 2007, Song \& Di Benedetto, 2008).

All in all, we assume that supplier collaboration enhances the firm's innovation performance. Indeed, the literature reports several potential advantages related to supplier collaboration, including: improved efficiency and effectiveness of future project collaboration (Dyer \& Ouchi, 1993), alignment of technological strategies with suppliers (Bonaccorsi, 1992), better and faster access to technological resources and knowledge (Ragatz et al., 1997; Bonaccorsi, 1997), lead time reduction (Clark, 1989; Wasti \& Liker, 1997; Ragatz et al. 1997), reduced development costs and time (Clark, 1989; Hartley, 1997), better product performance and design (Bonaccorsi \& Lipparini, 1994; Kamath \& Liker, 1994; Ragatz et al., 1997), better product quality (Dowlatshahi, 1992). In particular, we ground on studies showing that supplier collaboration could shorten development cycle time (Chen et al., 2010; Millson et al., 1992; Song \& Parry, 1999). Failure to involve supplier in production decisions may lead to high costs and low production capacity (Chen et al., 2010). Further, supplier collaboration enables product differentiation by obtaining information and expertise regarding new ideas and technologies that can help developing a highly innovative product (Song \& Di Benedetto, 2008). In other words:

\section{H4. A greater effort on supplier collaboration positively influences innovation} performance.

\subsection{Effect of strategic sourcing on innovation performance}

As noted previously, van Echtelt et al. (2008) distinguish between operational and strategic processes for supplier involvement: not only NPD requires to jointly perform operational activities with suppliers; strategic sourcing as an antecedents of NPD performance should also be considered.

Strategic sourcing refers to activities like reverse marketing and supplier selection. Monitoring the supply market let the firm access innovation by establishing a set of suppliers aligned to the technology roadmap and, at the same time, maintain the appropriate range of bookshelf technologies that might affect the market (Monczka et al., 2000). Johnsen (2009) shows that the latest research about collaborative NPD emphasizes the need for supplier selection (e.g., Song \& Benedetto, 2008; Schiele, 2006) as well as relationship development and adaptation (e.g., Petersen et al., 2003; Ragatz et al., 2002; Primo \& Amundson, 2002). Petersen et al. (2005) note that selecting the "right" supplier (good match of capabilities and culture) leads to improved performance. We therefore expect that:

H5. A greater effort on strategic sourcing positively influences innovation performance.

Insert Figure 1 here 


\section{Methodology}

\subsection{Sample and data collection}

The hypotheses were tested using data collected in winter 2009/2010 in ten countries in Europe and North America (Canada, Finland, France, Germany, Italy, the Netherlands, Spain, Sweden, United Kingdom, and the United States of America) through an online survey questionnaire about purchasing priorities, purchasing practices, and purchasing performance, using constructs derived from the literature.

The English version of the questionnaire was translated into different languages using the TRAPD (Translation, Review, Adjudication, Pre-testing and Documentation) procedure (Harkness et al., 2004) and subsequently tested by submitting it to a couple of purchasing executives in each country to check the clarity of the questions. Before and during the pretesting phase a special emphasis was laid on the quality of the construction of questions in order to reduce potential bias resulting from respondents' misleading cognition (Poggie, 1972; Schwarz \& Oyserman, 2001). In particular, we tried to concentrate our questions on observable data and to exclude every possible scope of interpretation. The final version of the survey tool was uploaded onto the project web-site and made visible only to respondents selected in the sampling procedure. The Internet survey offers higher levels of accuracy and reduces missing values due to either the respondent or some data entry mistakes (Boyer et al., 2002). Firms were sampled from the membership lists of the corresponding national purchasing associations. Sampling criteria were pre-agreed among the participating researchers. $65.7 \%$ of the companies in the sample are from the manufacturing sector, even though other industries are represented (see the Appendix). The corresponding firms were first contacted and asked for participation. Reminder e-mails and telephone calls were conducted after four weeks to those who had not responded. Following other similar key informant-based research studies (Cini et al., 1993; Cousins, 2005), the goal was to find the right person within the organisation who was able to respond to all of the questions about the purchasing strategy, the buyer-supplier relation, purchasing practices and performance. For this reason, mostly CPOs, VPs of Purchasing, Purchasing Directors and Purchasing Managers were involved. The respondents consisted of highly qualified purchasing professionals who had played important roles in the purchasing functions of their firms. After the data collection process, each country cleaned its own data in accordance with a common agreement to build a shared international database. The overall sample is made of 681 usable responses corresponding to an average response rate of $10 \%$, which is reasonable considering the length of the survey. However, only 498 companies provided sufficient information to test the hypotheses stated above (we excluded answers provided by companies that are not performing supplier collaboration and strategic sourcing processes as related to items in Table $3)$. The targeted companies are of various sizes and are mostly from the manufacturing sector, even if other industries are well represented. Non-respondent bias was tested by identifying the differences between the first wave of respondents and later returns (Scott \& Overton, 1997). The ANOVA shows no significant differences in terms of company size and sectors distribution). In addition, the ten country-specific subsamples were also proved to be appropriate in terms of pooling (Knoppen et al., 2010, 2011). See the Appendix for further details on the sample.

The core part of the survey focuses on a single purchasing category, autonomously selected by the respondent. This choice is due to the fact that companies frequently buy differently by category (i.e., a specific group of items, also known as a "purchasing group" or "commodity"). For instance, differences are noted between direct and indirect goods and among categories that are positioned differently within the Kraljic matrix (Kraljic, 1983). Yet, this is a quite rare approach in Purchasing and Supply Management research, which generally 
refers to the overall activity of the function. In our sample, respondents mainly address direct expenditures (about $80 \%$ of cases), whereas indirect (15\%) and capital (5\%) expenditures are less represented. Moreover, categories are homogeneously spread across different types in terms of strategic importance and supply risk, with a prevalence of strategic items.

Our focus on the category level is also original in respect the NPD literature, which often investigates single one-shot projects aimed at developing specific products or services. Even though this perspective is consistent with the idea that different categories should be studied separately, it does not allow to generalize conclusions beyond the horizon of the specific project. In other words, if a firm successfully manages the redesign of a specific component together with its supplier, nothing can be said about the next change of specifications, as one project is different from the other. Instead, by focusing on the category level we assess which practices the firms put in place and which results are obtained each time a given category is subject to NPD.

Given that we relied on a single respondent design, we controlled for common method bias in two ways: through the design of the study and through statistical control (Podsakoff et al., 2003). Regarding the survey, the research project was labelled as a broad overview of purchasing management and purchasing practices adoption. Therefore no explicit reference to the intention to test antecedents of innovation performance was evident. Thus, respondents' attention was not drawn to the relationships being targeted in this study. Questions including items and constructs related to each other in the general model were also separated in the questionnaire in order to prevent respondents from developing their own theories about possible cause-effect relationships. Furthermore, the questionnaire was carefully created and pretested and respondents were assured of strict confidentiality. Finally, we used different scales and formats for the independent and the criterion measures (Podsakoff et al., 2003). As a second mean to ensure against common method bias, we examined the unrotated factor solution (Podsakoff \& Organ, 1986). We were able to determine four factors that account within a range of 6 to 28 percent for the variance in the measures. Consequently, neither a single nor a general factor is likely to account for the majority of the covariance among the measures.

\subsection{Measures and their analysis}

Hypotheses were tested using structural equation modelling (SEM) with the maximum likelihood (ML) estimation method. Most SEM applications described in the literature are analysed with this methodology. The hypothesised model was tested statistically in a simultaneous analysis of the entire system of variables to determine the extent to which it was consistent with the data. Where goodness-of-fit is adequate, the model can be seen as a plausible explanation of postulated interactions between constructs. The research model is analysed and interpreted sequentially: first the assessment of the reliability and validity of the measurement model and secondly the assessment of the structural model (Hulland et al., 1996). Amos version 18 was used to estimate both the measurement model and the structural model. The ML algorithm was used to obtain the paths, the loadings, the weights, and the quality criteria. The operationalization of the constructs is based on existing measures, using six and seven point semantic differential scales. Constructs validity and reliability are detailed in Table 3 and 4.

In addition to the main variables in the model, we believe technological uncertainty is a powerful control variable that must be considered. Several studies emphasize the role technological uncertainty plays in stressing innovation as a critical success factor to compete, as well as the need to access other partners' know-how and complementary technologies (e.g. Lancioni \& Chandran, 2009; Martín-de Castro et al., 2011). For example, involving key suppliers early in NPD allows organizations to hedge its exposure against technological risk 
by improving the integration capability of new technologies into final products (Ettlie \& Pavlou, 2006; Bozdogan et al., 1998), and creating a bookshelf of embryonic technological innovations that may result useful in the future (Schilling, 2008). Similarly, Ragatz et al. (2002) along with Powell et al. (1996) conclude that NPD collaboration is particularly important in a context characterized by rapid technological change as it allows leveraging on suppliers knowledge and expertise. In the context of this study, we expect that different levels of technological uncertainty (meant as novelty and rate of change of the technology involved in the category for the buying firm) might influence both the category strategy and practices. Consequently, we use technological uncertainty as a control variable in order to validate the explanatory power of our research framework, for instance in terms of the scientifically confirmed effect of technological uncertainty on supplier collaboration.

The operationalization of category technological uncertainty is based on the approach of Ragatz et al. (2002) and Powel et al. (1996). According to this, each respondent had to rate "The extent to which technologies in this category are new" to his firm, "The extent to which technologies change in this category" and "The extent to which products/services are new" to his firm from 1 ("Extremely low") to 6 ("Extremely high").

In order to measure the category innovation strategy we followed the approach proposed by Hayes \& Wheelwright (1984), who consider strategy as a mix of competitive priorities. Innovation as a category priority can therefore be measured by looking at the rate of introduction of new product/services and time to market (Ward et al., 1990; Lagacé \& Bourgault, 2003). Respondents were asked to provide answers on a Likert-like scale ranging from 1 ("Not at all") to 6 ("Completely") regarding to what extent the management had emphasized the need to "improve time-to-market with suppliers" and "improve introduction rates of new/improved products/services" during the previous two years for the chosen category. Supplier collaboration has been measured by asking respondents to use a Likert-like scale to rate from 1 ("Extremely low") to 6 ("Extremely high") the "level of proficiency of the process (i.e., the level of quality in executing the process)" for the following processes: "Supplier development: the process of selecting suppliers for the chosen category as candidates for supplier development, and assisting suppliers in quality and cost improvement projects", "Supplier involvement into NPD: the process of managing the involvement of suppliers in the development of (new) products / services / processes / technologies for the chosen category", "Supplier integration in order fulfillment: the process of integrating suppliers for the chosen category in operations (e.g. joint production or inventory planning) and/or in the order fulfillment process". This reflects the intention to assess the quality of the buyer-supplier relation in processes that can typically affect innovation performance (e.g. van Echtelt et al., 2008; Chen et al., 2010; Zhao et al. 2011). Similarly, strategic sourcing has been measured by asking the "level of formalization of the process (i.e., to what degree the process is guided by written rules and procedures) for the chosen category" for: "Supply market analysis: the process of analyzing the supply market for the chosen category (e.g. searching for new suppliers, supply market structure, technological developments, price developments)", "Spend analysis: the process of analyzing the purchasing spend of the chosen category (e.g., current spend, spend developments, contract compliance)", "Sourcing strategy: the process of formulating a sourcing strategy for the chosen category", "Supplier selection and contracting: the process of sending out request for quotations, tendering /negotiating, and selecting suppliers for the chosen category". This reflects how much is the firm serious about strategic sourcing, provided that the level of formalization is a good proxy of the firm's effort in these processes (Miller, 1982; McCabe, 1987; Kim, 2007; Juha \& Pentii, 2008).

The measurement of purchasing professionals' knowledge is based on the approach of Tu et al. (2006), who understand manager knowledge as a vital element of absorptive capacity. According to this, respondents were asked to rank "The knowledge of purchasing manager(s) 
when making business decisions", "The knowledge of purchasing manager(s) when dealing with new technologies", "The knowledge of purchasing manager(s) when managing daily operations", and "The knowledge of purchasing manager(s) when dealing with human issues (e.g. human resource management, internal and external communications)" each from 1 ("Totally inadequate") to 6 ("Totally adequate").

Finally, in order to test the innovation outcomes of supplier involvement we referred to the established literature, which suggests that suppliers' contribution is expected to speed-up the development process and to improve products/services (either in term of costs or quality) (Clark, 1989; Koufteros et al., 2007; Primo \& Amundson, 2002). In order to limit the number of items considered without neglecting constructs reliability we condensed some of the measures used by scholars: respondent have been asked to what extent category performance improved compared to management targets on a Likert-like scale form 1 ("Much worse than target") to 7 ("Much better than target").

After the data collection we verified the measures by assessing reliability and unidimensionality of each of the five constructs, i.e. item-to-total correlations within each construct were examined (Churchill, 1979). In terms of structural equation modelling we followed the two steps of Anderson and Gerbing (1988). Our measurement model was tested with AMOS 18.0 using the maximum likelihood method (Arbuckle, 2009) and is able to provide to a great extent discriminant validity as well as convergent validity (Bagozzi \& Yi, 1988; Anderson \& Gerbing, 1988; Fornell \& Larcker, 1981). Only the composite reliability (CR) of one construct measured is slightly below.70, but still acceptable following Nunnally (1994). CR values of the remaining constructs attest to a great extent internal consistency of the measurement. The average variance extracted for innovation performance is below the threshold of .50 (Fornell \& Larcker, 1981; Bagozzi \& Yi, 1988), but none of the constructs violates the Fornell-Larcker criterion. Descriptive statistics and inter-correlations are shown in Table 2.

Insert Table 2 here

Following the recommendations of Bagozzi and Yi (1988) as well as Bagozzi and Baumgartner (1994) the quality of our model can be judged as sufficient. Table 3 comprises further results of the confirmatory factor analysis (CFA). All items were affirmed through confirmatory factor analysis (Table 3). The model consists of six multi-item constructs with a total of 18 indicators (see Figure 1). Two possible ways of evaluating model fit are the use of the chi-square goodness-of-fit statistic and the use of other absolute or relative fit indices $(\mathrm{Hu}$ $\&$ Bentler, 1999). It is quite common in management literature to avoid using the chi-square p-value as this measure is particularly sensitive to sample size and assumptions of normality (Hu \& Bentler, 1995). As a consequence other fit indices are preferred to the p-value. Some authors suggest to check for the ratio between chi-square value and degrees of freedom in the model, where cutoffs values ranges from $<2$ to $<5$ depending on the investigator (e.g., Byrne, 1989; Kelloway, 1998). Another way to evaluate the fit of a model is to use fit indices that have been offered to supplement the chi-square. Fit indices range from 0 to 1 , with values closer to 1 indicating good fit. Hu and Bentler (1999) recommend MLE-based fit indices and also suggest a two-index presentation strategy with, among others, the comparative fit index (CFI), and Gamma hat or root mean square error of approximation (RMSEA). An acceptable threshold for CFI is $>0.95$ whereas RMSEA is supposed to be lower than 0.05 . The CFA reveals a sufficient model fit attested through such fit indices for the measurement model (Bollen, 1989; Shah \& Goldstein, 2006): $\chi^{2}=146.1 ; \chi^{2} /$ d.f. $=1.27$; RMSEA=.023; CFI=.992. 
Insert Table 3 here

\section{Results}

The postulated path model produced a sufficient fit to the data $\left(\chi^{2}=185.27 ; \chi^{2} /\right.$ d.f. $=1.557$; RMSEA $=.033 ; \mathrm{CFI}=.982$ ). Table 4 shows the results of the hypotheses testing ${ }^{2}$.

Insert Table 4 here

According to hypothesis $\mathrm{H} 1 \mathrm{~b}$, more emphasis on innovation strategy leads to a higher effort on supplier collaboration. H1b is supported through our results $(\beta=.321, \mathrm{p}<.001)$. Similarly, H1a assumes that a higher emphasis on innovation strategy has a positive impact on strategic sourcing. Our results also provide support for H1a $(\beta=.128, \mathrm{p}<.05)$.

In regard to the hypotheses $\mathrm{H} 2$ and $\mathrm{H} 3$ we postulate that a higher level purchasing knowledge has a positive effect on the supplier collaboration and on strategic sourcing. Our findings indicate that $\mathrm{H} 2$ is supported with a parameter estimate of $.340(\mathrm{p}<.001)$ as well as hypothesis H3 $(\beta=.296, p<.001)$. Finally, the hypotheses H4 and H5 follow the argumentation that a higher level of innovation performance can be achieved through more emphasis on supplier collaboration and strategic sourcing. Our findings support both $\mathrm{H} 4$ ( $\beta$ $=.336, \mathrm{p}<.001)$ and $\mathrm{H} 5(\beta=.156, \mathrm{p}<.014)$.

As for technological uncertainty, which we used as a control variable, we found that a higher level of technological uncertainty has a positive effect on the innovation strategy at the purchasing category level $(\beta=.435, \mathrm{p}<.001)$. Also, technological uncertainty positively affects strategic sourcing $(\beta=.197(\mathrm{p}<.01)$, yet not supplier collaboration $(\beta=.044, \mathrm{p}=.476)$.

All path significances and coefficients of determination are illustrated in Table 4.

\footnotetext{
${ }^{2}$ As part of the review process, in order to ensure the reliability of our model, we completely re-run all statistical tests through both partial least square regression using the Smart PLS software and OLS regression using the SPSS software, including control variables on innovation performance related to size and industry of the firm (which we found not significant). Results obtained confirm the validity both of the measures and the structural model.
} 


\section{Discussion}

The study examines innovation outcomes in a business-to-business context. We consider the perspective of the buying firm that is leveraging on its supply base to achieve innovation. In particular, we show that firms dedicating to innovation not only invest in strategic sourcing (i.e. actively scout and maintain the supply base) but also promote supplier collaboration (i.e. supplier development as well as involvement into the buying firm's processes). This result is in line with previously separated streams of literature. Industrial marketing and purchasing scholars have focused increased attention on buyer-supplier relationships in industrial markets during the past decades. On the one hand, suppliers have been conceived as main contributors to the new product development process, for the benefit of their customers' innovation capabilities. On the other hand, the purchasing function has clearly emerged as a pivotal interface and process owner of collaborative buyer-supplier relationships.

In this regard, our paper contributes to the understanding and management of business interrelations on both sides, by considering both outward and inward oriented activities. Not only external suppliers are an important cornerstone of the buying firm's innovation strategy, but also internal sourcing processes managed by the purchasing department are at stake.

The evidence provided about purchasing knowledge further confirms the role played by the purchasing department. Purchasing managers possessing a thorough preparation (beyond technical knowledge related to their tasks) are able to foster the adoption of both aforementioned practices (i.e. supplier collaboration and strategic sourcing), thus ultimately contributing to the innovation outcomes.

Indeed, we clearly assess the beneficial effect of such practices on innovation outcomes: strategic sourcing and supplier collaboration significantly improve the innovation performance the buying firm can get from suppliers.

Finally, as an important corollary to our results, we also demonstrate that the firm dedication to innovation and therefore to invest in buyer-supplier collaborative processes is particularly critical in presence of high technological uncertainty characterizing the input provided by suppliers.

These results have important implications for managers and researchers. They can be interpreted both from the perspective of the buying firm willing to increase the innovation effort and from the perspective of suppliers that would like to contribute such effort. Accordingly, we discuss theoretical and managerial implications from our findings.

\subsection{Theoretical implications}

Aggregating several empirical studies, Chen et al. (2010) provide theoretical support to prominent models of new product performance. The model we propose (see Figure 1) is consistent with the strategic orientation and organizational capability model drawn by Kessler \& Chakrabarti (1996) as well as the centrifugal and centripetal model by Sheremata (2000). Moreover, Chen et al. (2010) argue that it is important to identify salient and cross-situational factors that facilitate or hinder fast development of new products. To this end, they identify four groups of NPD speed antecedents (i.e. project, process, strategy, and team) that are consistent with the antecedents we are addressing in this study. Furthermore, instead of considering all antecedents at the same conceptual level, we argue that a path can be identified among these antecedents: the latent exogenous variables of our postulated model are understood as drivers for the sources of competitive advantages and ultimately the success in the field of innovation. Sources of advantages and the positional advantage comprise latent endogenous factors of our causal model, as shown in Figure 1.

We find largely support for our postulated research model. Firstly, more emphasis on innovation strategy has a positive effect on the dedication to supplier collaboration (H1b). 
When buying strategic components or services, different collaborations within a development project have to be set up and managed in order to achieve technical performance targets and the targeted costs (van Echtelt et al., 2008). As a matter of fact, the literature about businessto-business relationship largely suggests that suppliers are a key stakeholder of new product development, even tough previous empirical evidence was not always straightforward. Similarly, strengthening innovation strategy positively influences the dedication to strategic sourcing (H1a). Companies that concentrate on innovation goals increasingly have to look for help beyond their boundaries. This strengthens the importance of strategic sourcing as one key process to effectively leverage the supply base (Lindner et al., 2003). In turn, the study also supports the existence of a substantial and positive link between purchasing knowledge and both supplier collaboration (H2) and strategic sourcing (H3). Purchasing managers' knowledge emerges as an intangible asset for an effective buyer-supplier interface. Competent buyers can significantly contribute to NPD by identifying and selecting valuable supplier knowledge and consequently fostering promising supplier collaboration (Johnston, 2004; Knudsen, 2007). Therefore, purchasing knowledge should be considered as an important catalyst of buyer-supplier collaborative innovation.

Furthermore, our findings support the definition of aforementioned practices as good (if not best) practices. Firstly, we are able to show that a stronger dedication to supplier collaboration has a positive impact on innovation performance (H4). Our findings comply with extant literature about supplier collaboration, which might lead to, e.g., better product quality and product performance (Bonaccorsi \& Lipparini, 1994; Dowlatshahi, 1992; or Ragatz et al., 1997) or better and faster access to resources / knowledge (Bonaccorsi, 1997). Certainly, successful collaboration with vendors must take various factors into account, such as tier structure, inter-company communication, intellectual property agreements and degrees of responsibilities for specific tasks or the alignment of supplier's capabilities with regard to the degree of supplier involvement (Handfield et al., 1999).

Secondly, innovation performance is influenced through a greater dedication to strategic sourcing (H5). According to Petersen et al. (2005), selecting the right supplier and integrating the supplier early into NPD results in a better performance; our findings support this causality. In the case of absorptive capacity Chen et al. (2009) identify a positive impact on innovation performance. Referring to the approach of Tu et al. (2006) who postulates that (purchasing) manager knowledge is as a vital element of absorptive capacity, our results suggest an indirect impact of purchasing knowledge on innovation, through supplier collaboration and strategic sourcing. Finally and as a matter of fact, the importance of the purchasing function's role in detecting and promoting innovation potentials from the supply market and its influence on NPD outcomes becomes evident.

In addition, our analysis is able to identify a definite and positive relation between technological uncertainty and innovative strategy, suggesting that the purchasing department should align its strategy to the supply market and input category characteristics in order to cope with such uncertainty (McIvor \& Humphreys, 2004). Interestingly, our results do not support a direct impact on supplier collaboration, but only on strategic sourcing. Firms perceiving high technological uncertainty are often facing a radical or disruptive innovation context. As a matter of fact, disruptive technologies usually take place in remote or emerging markets (Christensen \& Bower, 1996). In contrast to sustaining technological changes that are employed in established markets and where supplier collaboration is an appropriate instrument, disruptive innovations often lead to a shift in the market place (Abernathy \& Clark, 1985). According to this, sourcing has to consider different eventualities for reducing risk and ensuring the required knowledge base in dependence to the degree of technological uncertainty. For instance, under the condition of high technological uncertainty multiple sourcing allows the buying firm to hedge its exposures against technological risk. It seems 
therefore reasonable to assume that - in presence of high technological uncertainty - the buying firm will prefer to hedge against possible disruptions through appropriate sourcing processes rather than through risky collaborations with suppliers.

\subsection{Managerial implications}

From a managerial perspective our results have several implications for practitioners in industrial markets. The model described in Figure 1 shows a clear path leading to improve the innovation performance that one buying firm can get from its suppliers. The path starts with the definition of an innovation strategy that is consistent with the purchasing category considered. In order to fully integrate the innovation strategy into the supply strategy, purchasing managers need to consider the individual and sometimes conflictive objectives on the corresponding category level. To this regard, we expect that categories relatively more subject to technological uncertainty will require more formal innovation objectives than standard, non critical items.

Next, in order to translate strategic objectives into actual results, strategic sourcing and supplier collaboration are key to a successful implementation. Previous research has already shown that companies can learn from their suppliers through close relationships (Chen et al., 2009; García-Morales et al., 2007). Our findings supplement this insight by identifying the purchasing department as the catalyst of collaborative innovation. Overall, we demonstrate that supplier collaboration and purchasing involvement in NPD actually leads to improved innovation performance.

Important success factors are the early involvement of representatives in NPD projects and an integrated evaluation of product design (van Echtelt et al., 2008). If that can be done within co-design relationships with partner suppliers that own complementary competences to the firm's, we also show that a constant effort into strategic sourcing can benefit per se the firm innovation capability. For example, mature purchasing departments typically apply portfolio models to cluster different types of purchased items and tailor sourcing strategies accordingly. Being able to distinguish between categories that require a joint NPD effort with suppliers and categories that can be totally entrusted to capable suppliers as well as to define appropriate contractual arrangements with each supplier appear as powerful enablers of innovation performance.

Furthermore, purchasing knowledge emerges as a prerequisite for success in both supplier collaboration and strategic sourcing. Companies cannot identify capable suppliers or utilize sophisticated purchasing tools without having the corresponding knowledge to do so. Consequently, supply management can represent an innovation function within companies since it is able to take responsibility for the selection of promising suppliers and for the pursuance of new ideas in terms of NPD. Supply management as an innovation function is the impetus of modernization, which continuously focuses on new business opportunities and communicates directly to members of the executive board of a company. To achieve this goal, the innovation strategy at the corporate level should be communicated to purchasing professionals, so that they can properly translate it into a compelling category strategy. Training and incentive schemes in the purchasing function can facilitate to achieve the strategic fit. Supply managers should therefore be reassured regarding positive outcomes out of collaborations with vendors when innovation is a crucial competitive priority.

Looking at our results from the supplier's perspective, one can gain further insights. When approaching an industrial customer willing to improve innovation performance, the supplier should evaluate the customer familiarity with integrated new product development as well as the status and maturity of the purchasing function inside the firm. Inter-company processes are more complex to manage and sometime backfire affecting performance outcomes. 
Therefore the supplier should carefully evaluate whether or not to commit for an integrated new product development effort, making sure that the customer has proper policies and systems in place.

\section{Conclusion and limitations}

The study examines the innovation related processes that are necessary to effectively manage the collaboration with suppliers, monitor supply markets and leverage purchasing knowledge in order to increase innovation outcomes.

Using structural equation modelling we empirically investigate the link between the firm innovation strategy and two purchasing-related practices (i.e. supplier collaboration and strategic sourcing) as well as the purchasing (manager) knowledge. We also hypothesize a positive relationship between purchasing-related practices and innovation performance. Our findings largely suggest acceptance of the postulated model. Previous research (Wynstra et al., 2003; Wagner 2003; McGinnis \& Vallopra, 2001) was clear about this possibility, yet largely case based. We instead provide empirical foundations to the positive effect of supplier collaboration, strategic sourcing and purchasing professional knowledge on innovation performance by analyzing a large data set of 498 entries. Based on our findings, purchasing senior managers are therefore advised to take several actions regarding - for instance purchasing professionals training needs or adequate buyer-supplier collaboration configuration. Further, we demonstrated the enabling role entrusted to purchasing professionals. We also show that technological uncertainty calls for specific actions from managers in terms of strategic sourcing as well as for mechanisms to avoid negative effects on buyer-supplier relations.

This study has its limitations, some of which will serve as the stimulus for future work. First of all, we focus on specific supplier and purchasing contributions to innovation results. Further research might investigate other factors that are able to affect the innovation outcomes of the buying firm, such as the level of internal integration (i.e. the level of integration between purchasing, R\&D, and other functions involved in NPD), the level of technical expertise of suppliers and/or buyers, or the collaboration with final customers.

The contribution of purchasing knowledge towards category innovation performance is only indirectly considered within our analysis. Since it is common sense that the purchasing skills are able to provide access to supplier skills, it would be interesting to know to which degree the purchasing department is able to directly influence innovation outcomes at the category level. Similarly, different types of category clusters might be taken into account, in order to test how contingent factors influence the model significance.

Another open issue in the literature deals with possible drawbacks of supplier involvement in terms of development costs. Future research might contribute to answer this question by considering performance trade-offs in the context of collaborative NPD. Our study did not specifically look at small- and medium-sized enterprises (SMEs) and their specific innovation potential. Extending our work to examine SMEs' innovation potentials would shed further light on SME as innovation catalysts.

Finally, we only partially considered purchasing potential contribution to the firm innovation strategy by including purchasing professionals' knowledge as a construct in our model. More in-depth analysis might lead to isolate other factors explaining the buyersupplier relationship and the purchasing role in it. 


\section{References}

Abernathy, W.J., Clark, K.B., 1985. Mapping the winds of creative destruction. Research Policy, 14(1), 3-22. Anderson E., Weitz B., 1992. The Use of Pledges to Build and Sustain Commitment in Distribution Channels. Journal of Marketing Research, 29(1), 18-34.

Anderson, J.C., Gerbin, D.W., 1988. Structural Equation Modelling in Practice: A Review and Recommended Two-Step Approach. Psychological Bulletin, 103(3), 411-423.

Anderson, S.W., Dekker, H.C., 2005. Management control for market transactions: The relation between transaction characteristics, incomplete contract design, and subsequent performance. Management Science, (51)12, 1734-1752.

Anklesaria, J., Burt, D.N., 1987. Personal Factors in the Purchasing/Engineering Interface. Journal of Purchasing and Materials Management 23(1), 190-202.

Araujo, L., Dubois, A., Gadde, L.E., 1999. Managing Interfaces with Suppliers, Industrial Marketing Management, 28(5), 497-506.

Arbuckle, J.L., 2009. Amos 18 User's Guide. SPSS Inc.: Chicago.

Atuahene-Gima, K., 1995. An Exploratory Analysis of the Impact of Market Orientation on New Product Performance. Journal of Product Innovation Management, 12, 275-293.

Bagozzi, R.P., Baumgartner, H., 1994. The Evaluation of Structural Equation Modelsand Hypothesis Testing. In: Bagozzi, R.P., Ed. Principles of Marketing Research, 386-422, Wiley John \& Sons: Cambridge.

Bagozzi, R.P., Yi, Y., 1988. On the Evaluation of Structural Equation Models. Journal of Academy of Marketing Science, 16(1), 74-94.

Barney, J.B., 1986. Strategic factor markets: expectations, luck, and business strategy. Management Science 32(10), 1231-1241.

Barney, J.B., 1991. Firm resources and sustained competitive advantage. Journal of Management 17(1), 99-120.

Bidault, F., Butler, C., Despres, C., 1998. The drivers of cooperation between buyers and suppliers for product innovation. Research Policy 26(7/8), 719-773.

Birou, L.M., Fawcett, S.E., 1994. Supplier involvement in integrated product development: a comparison of US and European practices, International Journal of Physical Distribution and Logistics Management, 24(5), 4-14.

Bollen, K.A., 1989. Structural Equations with Latent Variables. John Wiley \& Sons: New York.

Bonaccorsi A., Lipparini A., 1994. Strategic partnerships in new product development: An Italian case study, Journal of Product Innovation Management, 11(2), 134-145.

Bonaccorsi, A., 1992. On the relationship between firm size and export intensity. Journal of International Business Studies, 23(4), 605-635.

Bonaccorsi, A., 1997. The External and Internal Integration of Resources: Evidence from a survey on procurement practices of medium and large manufacturing firms, Conference Proceedings of the 6th IPSERA Annual Conference, Ischia, 24-26 March, T3/1-20.

Boyer, K.K. et al., 2002. Print versus electronic surveys: a comparison of two data collection methodologies. Journal of Operations Management, 20(4), 357-373.

Bozdogan, K., Deyst, J., Hoult, D., 1998. Architectural innovation in product development through early supplier integration. $R \& D$ Management, 28(3), 163-173.

Braunscheidel, M. J., Suresh, N. C., 2009. The organizational antecedents of a firm's supply chain agility for risk mitigation and response. Journal of Operations Management, 27(2), 119-140.

Byrne, B.M., 1989. A primer of LISREL: basic applications and programming for confirmatory factor analytic models. New York: Springer-Verlag.

CAPS, 2011. Innovation Sourcing: Contributing to Company Competitiveness, Tempe, Arizona.

Carr, A.S., Pearson, J.N., 2002. The impact of purchasing and supplier involvement on strategic purchasing and its impact on firm's performance. International Journal of Operations \& Production Management, 22(9), 1032-1053

Carr, A.S., Smeltzer, L.R., 1997. The relationship of strategic purchasing to supply chain management, European Journal of Purchasing and Supply Management, 5(1), 43-51.

Chen, I., Paulraj, A., Lado, A., 2004. Strategic purchasing, supply management, and firm performance. Journal of Operations Management, 22(5), 505-523.

Chen, J., Damanpour, F., Reilly, R. R., 2010. Understanding antecedents of new product development speed: A meta-analysis. Journal of Operations Management, 28(1), 17-33.

Chen, Y.-S., Lin, M-J.J., Chang, C.-H., 2009. The positive effects of relationship learning and absorptive capacity on innovation performance and competitive advantage in industrial markets. Industrial Marketing Management, 38(2), 152-158.

Chesbrough, H., Crowther, A.K., 2006. Beyond high tech: early adopters of open innovation in other industries. $R$ and D Management, 36(3), 229-236. 
Christensen, C. M., Bower, J. L., 1996. Customer power, strategic investment, and the failure of leading firms. Strategic Management Journal, 17(3), 197-218.

Christiansen, P. E., Maltz, A., 2002. Becoming an "Interesting" Customer: Procurement Strategies for Buyers without Leverage. International Journal of Logistics Research and Applications, 5(2), 177-196.

Churchill, G.A., 1979. A paradigm for developing better measures of marketing constructs. Journal of marketing research, 16(1), 64-73.

Cini, M., Moreland R., Levine J., 1993. Group staffing levels and responses to prospective and new group members. Journal of Personality and Social Psychology 65(4), 723-734.

Clark, K.B., 1989. Project scope and project performance: the effect of parts. Management Science, 35(10), p. 1247

Cooper, R.G., 1999. From experience: the invisible success factors in product innovation, Journal of Product Innovation Management, 16(2), 115-133.

Cousins, P., Spekman, R., 2003. Strategic supply and the management of inter-and intra-organisational relationships. Journal of Purchasing and Supply Management, 9(1), 19-29.

Cousins, P.D., 2005. The alignment of appropriate firm and supply strategies for competitive advantage. International Journal of Operations \& Production Management, 25(5), 403-428.

Cox, A., 2001. Understanding buyer and supplier power: A framework for procurement and supply competence. The Journal of Supply Chain Management, 37(2), 8-15.

Das, A., Narasimhan, R., Talluri, S., 2006. Supplier integration - Finding an optimal configuration. Journal of Operations Management, 24(5), 563-582.

Day, G., Wensley, R., 1988. Assessing advantage: a framework for diagnosing competitive superiority. Journal of Marketing 52(2), 1-20.

Dowlatshahi, S., 1992. Purchasing's role in a concurrent engineering environment. International Journal of Purchasing and Materials Management, 28(1), 21-25.

Dowlatshahi, S., 1998. Implementing early supplier involvement: a conceptual framework. International Journal of Operations \& Production Management, 18(2), 143-167.

Dyer, J.H., Ouchi, W.G., 1993. Japanese-style partnerships: giving companies a competitive edge. Sloan Management Review, 35, 51-63.

Edquist, C.,, 1997. Systems of innovation approaches-their emergence and characteristics. In: Edquist C., (Ed.) Systems of innovation. Technologies, institutions and organizations. Pinter, London, 1-35.

Ellram, L.M., Carr, A., 1994. Strategic Purchasing: A History and Review of the Literature. International Journal of Purchasing and Materials Management, 30(1), 9-19.

Ellram, L.M., Pearson, J.N., 1993. The Role of the Purchasing Function: Toward Team Participation. Journal of Supply Chain Management, 29(3), 2-9.

Ettlie, J.E., Pavlou, P.A., 2006. Technology-based new product development partnerships. Decision Sciences 37(2), 117-147.

Flynn, B.B., Huo, B., Zhao, X., 2010. The impact of supply chain integration on performance: A contingency and configuration approach. Journal of Operations Management, 28(1), 58-71.

Fornell, C., Larcker, D.F., 1981. Evaluation Structural Equation Models With Unobservable Variables and Measurement Error. Journal of Marketing Research, 18(1), 39-50.

Freeman C, Soete L, 1997. The economics of industrial innovation, 3rd edn. Continuum, London.

Frohlich, M.T., Westbrook, R., 2001. Arcs of integration: an international study of supply chain strategies. Journal of Operations Management, 19(2), 185-200.

Gadde L.E., Håkansson, H., 1994. The changing role of purchasing: reconsidering three strategic issues. European Journal of Purchasing \& Supply Management, 1(1), Pages 27-35

García-Morales, V.J, Ruiz-Moreno, A., Llorens-Montes, F.J., 2007. Effects of technology absorptive capacity and technology proactivity on organizational learning, innovation and performance: An empirical examination. Technology Analysis \& Strategic Management, 19(4), 527-558.

Garcia, R., Calantone, R., 2002. A critical look at technological innovation typology and innovativeness terminology: a literature review. Journal of Product Innovation Management, 19, 110-132.

Grant, R.M., 1996. Toward a Knowledge-based Theory of the Firm. Strategic Management Journal, 17, 109-122.

Hakansson, H., Eriksson, A.K., 1993. Getting innovations out of supplier networks. Journal of Business-toBusiness Marketing, 1(3), 3-34.

Handfield, R.B., Ragatz, G.L., Petersen, K.J., and Monczka, R.M., 1999. Involving Suppliers in New Product Development? California Management Review, 42, p.59-82.

Harkness, J., Pennell, B., Schoua-Glusberg, A. (2004). Survey Questionnaire Translation and Assessment. Pp. 453-473 in S. Presser, J. M. Rothgeb, M. P. Couper, J. T. Lessler, E. Martin, J. Martin \& E. Singer (Eds.). Methods for Testing and Evaluating Survey Questionnaires. Hoboken, NJ. 
Hartley, J., 1997. Managing the buyer-supplier interface for on-time performance in product development. Journal of Operations Management, 15(1), 57-70.

Hartmann, E., Kerkfeld, D., \& Henke, M. (2012). Top and bottom line relevance of purchasing and supply management. Journal of Purchasing and Supply Management, 1-13.

Hayes RH, Wheelwright SC, 1984. Restoring our competitive edge: competing through manufacturing. Wiley publications.

Henard, D.H. \& Szymanski, D.M., 2001. Why Some New Products Are More Successful Than Others. Journal of Marketing Research, 38(3), 362-375.

Henke, J., Zhang, C., 2010. Increasing supplier-driven innovation. MIT Sloan Management Review, USA), Winter.

Hillebrand, B., Biemans, W.G., 2004. Links between Internal and External Cooperation in Product Development: An Exploratory Study. Journal of Product Innovation Management, 21(2), 110-122.

Hu, L., Bentler, P.M., 1998. Fit indices in covariance structure modeling: Sensitivity to underparameterized model misspecification. Psychological Methods, 3(4), 424-453.

Hulland, J.S., Chow, Y.H., University of Western Ontario. Western Business School. Research and Publications, \& Lam, S. Y. (1994). Use of Causal Models in Marketing Research: a Comprehensive Review, 28-56.

Inemek, A., Matthyssens, P., 2012. The impact of buyer-supplier relationships on supplier innovativeness: An empirical study in cross-border supply networks. Industrial Marketing Management, 1-15.

Jackson, S.E., Hitt, M.A., DeNisi, A.S., 2003. Managing knowledge for sustained competitive advantage: Designing strategies for effective human resource management. Pfeiffer.

Jayaram, J., Tan, K.-C., 2010. Supply chain integration with third-party logistics providers. International Journal of Production Economics, 125(2), 262-271.

Johnsen, T.E., 2009. Supplier involvement in new product development and innovation: Taking stock and looking to the future. Journal of Purchasing and Supply Management, 15(3), 187-197.

Johnston, D., 2004. Effects of supplier trust on performance of cooperative supplier relationships. Journal of Operations Management, 22(1), 23-38.

Juha, M. \& Pentti, J., 2008. Managing risks in organizational purchasing through adaptation of buying centre structure and the buying process. Journal of Purchasing and Supply Management, 14(4), 253-262.

Kamath, R.R., Liker, J.K., 1994. A second look at Japanese product development. Harvard Business Review, Vol. 72, 154-73.

Kelloway, E.K., 1998. Using LISREL for structural equation modeling: a researcher's guide. Thousand Oaks: Sage Publications.

Keough, M., 1994. Buying your way to the top. Director, 72-75.

Kessler, E.H., Chakrabarti, A.K., 1996. Innovation speed: a conceptual model of context, antecedents and outcomes. Academy Management Journal 21(4), 1143-1191.

Kim, S., 2007. Organizational structures and the performance of supply chain management. International Journal of Production Economics, 106(2), 323-345.

Knoppen, D. et al., 2011. Pooling Survey Data in the Operations and Supply Management Literature: A Review and Illustration of Equivalence Tests. In Proceedings of the XX IPSERA conference, April 10-13. Maastricht, 1-10.

Knoppen, D., et al., 2010. Analysis of Equivalence Among Sub-Samples: Preliminary Results of the International Purchasing Survey. Proceedings of the 17th International Annual EurOMA Conference, 6-9 June 2010, Portugal.

Knudsen, M.P., 2007. The Relative Importance of Interfirm Relationships and Knowledge Transfer for New Product Development Success. Journal of Product Innovation Management, 24(2), 117-138.

Koufteros, X. A., Edwin Cheng, T.C. \& Lai, K.-H., 2007. "Black-box" and "gray-box" supplier integration in product development: Antecedents, consequences and the moderating role of firm size. Journal of Operations Management, 25(4), 847-870.

Koufteros, X., Marcoulides, G. a., 2006. Product development practices and performance: A structural equation modeling-based multi-group analysis. International Journal of Production Economics, 103(1), 286-307.

Koufteros, X.A., Vonderembse, M.A., Jayaram, J., 2005. Internal and external integration for product development: the contingency effects of uncertainty, equivocality, and platform strategy. Decision Sciences 36(1), 97-133.

Kraljic, P., 1983. Purchasing must become supply management. Harvard business review, 4, 109-117.

Krause, D.R. \& Wagner, S.M. (2008). An Investigation of Supplier Development and Its Role in New Product Development, CAPS research.

Krause, D.R., 1999. The antecedents of buying firms' efforts to improve suppliers. Journal of Operations Management, 17(2), 205-224.

Krause, D.R., Pagell, M., Curkovic, S., 2001. Toward a measure of competitive priorities for purchasing. Journal of Operations Management, 19(4), 497-512. 
Lagacé, D., Bourgault, M., 2003. Linking manufacturing improvement programs to the competitive priorities of Canadian SMEs, Technovation, 23(8), 705-715.

Lakemond, N., Echtelt, F., Wynstra, F., 2001. A Configuration Typology for Involving Purchasing Specialists in Product Development. The Journal of Supply Chain Management, 37(4), 11-20.

Lancioni, R. A., Chandran, R., 2009. Managing knowledge in industrial markets: New dimensions and challenges. Industrial Marketing Management, 38(2), 148-151.

Lindner, J.C., Jarvenpaa, S.L., Davenport, T.H., 2003. Toward an Innovation Sourcing Strategy, MIT Sloan Management Review, 44(4), 43-49.

Luzzini, D., Caniato, F., Ronchi, S., Spina G., 2012. A transaction costs approach to purchasing portfolio management. International Journal of Operations and Production Management, 1-28.

Macbeth, D. K., 1994.The role of purchasing in a partnering relationship. European Journal of Purchasing \& Supply Management, 1(1), 19-25.

Mahajan, V., Wind, J., 1991. New product models, practice, shortcomings and desired improvements, Report no. 91-125, Marketing Science Institute, Cambridge, MA.

Martín-de-Castro, G., Delgado-Verde, M., López-Sáez, P., Navas-López, J. E., 2010. Towards “An Intellectual Capital-Based View of the Firm": Origins and Nature. Journal of Business Ethics, 98(4), 649-662.

McCabe, D.L., 1987. Buying Group Structure: Constriction at the Top. The Journal of Marketing, 51(4), 89 - 98.

McGinnis, M. A., Vallopra, R.M. 1999a. Purchasing and supplier involvement: issues and insights regarding new product success. Journal of Supply Chain Management, 35(2), 4-15

McGinnis, M. A., Vallopra, R.M. 1999b. Purchasing and supplier involvement in process improvement: a source of competitive advantage. Journal of Supply Chain Management, 35(3), 42-50.

McGinnis, M., Vallopra, R., 2001. Managing Supplier Involvement in process improvement in manufacturing. Journal of Supply Chain Management, August), 48-53.

McIvor, R., Humphreys, P., 2004. Early supplier involvement in the design process: Lessons from the electronics industry. International Journal of Management Science, 32, 179-199.

Mendez, E.G., Pearson, J.N., 1994. Purchasing's Role in Product Development: The Case for Time-Based Strategies. Journal of Supply Chain Management, 30(1), 2-12.

Miller, D., 1982. Evolution and revolution: a quantum view of structural change in organizationa. Journal of Management Studies, 19(2), 131-151.

Millson, M.R., Raj, S.P., Wilemon, D., 1992. A survey of major approaches for accelerating new product development. Journal of Product Innovation Management, 9 (1), 53-69.

Modi, S.B., Mabert, V. a., 2007. Supplier development: Improving supplier performance through knowledge transfer. Journal of Operations Management, 25(1), 42-64.

Monczka, R., Trent, R., \& Handfield, R., 2005. Purchasing and Supply Chain Management. 3rd ed., Batesville.

Monczka, R.M., Handfield, R.B., Scannell, T.V., Ragatz, G.L., Frayer, D.L., 2000. New Product Development: Strategies for Supplier Integration. Milwaukee: ASQ Quality Press.

Nijssen, E.J., Biemans, W.G., De Kort, J.F., 2002. Involving purchasing in new product development. $R \& D$ Management, 32(4), 281-289.

Nunnally, J.C., 1994. Psychometric Theory. 3rd ed., McGraw-Hill: New York.

Parker, H.(2000. Interfirm collaboration and the new product development process. Industrial Management \& Data Systems, 100(6), 255-260.

Petersen, K.J., Handfield, R.B., Ragatz, G.L., 2003. A Model of Supplier Integration into New Product Development. Journal of Product Innovation Management, 20(4), 284-299.

Petersen, K.J., Handfield, R.B., Ragatz, G.L., 2005. Supplier integration into new product development: coordinating product, process and supply chain design. Journal of Operations Management, 23, 371-388.

Podsakoff, P.M., MacKenzie, S.B., Lee, J.-Y., and Podsakoff, N.P., 2003. Common Method Biases in Behavioral Research: A Critical Review of the Literature and Recommended Remedies. Journal of Applied Psychology, 88(5), 879-903.

Podsakoff, P.M., Organ, D.W., 1986. Self-reports in Organizational Research: Problems and Prospects. Journal of Management, 12(4), 531-544.

Poggie, J., 1972. Toward quality control in key informant data. Human Organization, 31(1), 23-30.

Powell, W., Koput, W., Smith-Doerr. L., 1996. Interorganizational Collaboration and the Locus of Innovation: Networks of Learning in Biotechnology. Administrative Science Quarterly, 41(1), 116-145.

Prahinski, C., Benton, W., 2004. Supplier evaluations: communication strategies to improve supplier performance. Journal of Operations Management, 22(1), 39-62.

Primo, M., Amundson, S.D., 2002. An exploratory study of the effects of supplier relationships on new product development outcomes. Journal of Operations Management, 20(1), 33-52.

Quinn, J.B., Hilmer, F.G., 1994. Strategic Outsourcing. Sloan Management Review, 35(1), 43-55.

Ragatz, G.L., Handfield, R.B. Scannell, T.V., 1997. Success factors for integrating suppliers into new product development. Journal of product innovation management, 14(3), 190-202. 
Ragatz, G.L., Handfield, R.B., Petersen, K.J., 2002. Benefits associated with supplier integration into new product development under conditions of technological uncertainty. Journal of Business Research, 55, 389-400.

Rajagopal, S., Bernard, K.N. 1993. Strategic Procurement and Competitive Advantage. International Journal of Purchasing and Materials Management, 29(3), 12-20.

Ramsey, J., 2001. The resource based perspective, rents, and purchasing's contribution to sustainable competitive advantage. Journal of Supply Chain Management. 37(2), 38-47

Reck, R.F., Long, B.G., 1988. Purchasing a competitive weapon. International Journal of Purchasing and Materials Management, 24(4), 3-6.

Roberts, E.B., 2001. Benchmarking Global Strategic Management of Technology. Survey of the word's largest R\&D performers reveals, among other trends, a greater reliance upon external sources of technology. Research Technology Management, 44(2), 25-36.

Schiele, H., 2006. How to distinguish innovative suppliers? Identifying innovative suppliers as new task for purchasing. Industrial Marketing Management, 35(8), 925-935.

Schiele, H., 2010. Early supplier integration: the dual role of purchasing in new product development. $R \& D$ Management, 40(2), 138-153.

Schiele, H., Veldman, J. \& Hüttinger, L., 2011. Supplier Innovativeness and Supplier Pricing: the Role of Preferred Customer Status. International Journal of Innovation Management, 15(01), 1-27.

Schilling M., 2008. Strategic management of technological innovation, Chapter 8.

Schwarz, N., Oyserman, D., 2001. Asking questions about behavior: Cognition, communication, and questionnaire construction. American Journal of Evaluation, 22(2), 127-160.

Scott., J.A., Overton, T.S., 1977. Estimating Nonresponse Bias in Mail Surveys. Journal of Marketing Research, 14(3), 396-402.

Shah, R., Goldstein, S., 2006. Use of structural equation modeling in operations management research: Looking back and forward. Journal of Operations Management, 24(2), 148-169.

Sheremata, W.A., 2000. Centrifugal and centripetal forces in radical new product development under time pressure. Academy of Management Journal 25, 2), 389-418.

Smals, R. G. M., Smits, A. A. J., 2012. Value for value-The dynamics of supplier value in collaborative new product development. Industrial Marketing Management, 41(1), 156-165.

Song, L. Z., Song, M., Di Benedetto, C. A., 2011. Resources, supplier investment, product launch advantages, and first product performance. Journal of Operations Management, 29(1-2), 86-104.

Song, M., Di Benedetto, C.A., 2008. Supplier's involvement and success of radical new product development in new ventures. Journal of Operations Management, 26(1), 1-22.

Song, M., Parry, M., 1999. Challenges of managing the development of breakthrough products in Japan. Journal of Operations Management, 17, 665-688.

Squire, B., Cousins, P. D., Lawson, B., Brown, S., 2009. The effect of supplier manufacturing capabilities on buyer responsiveness - the role of collaboration. International Journal of Operations and Production Management, 29(8), 766-788

Swink, M. \& Song, M., 2007. Effects of marketing-manufacturing integration on new product development time and competitive advantage. Journal of Operations Management, 25(1), 203-217.

Teece D. J., 2010. Business Models, Business Strategy and Innovation. Long Range Planning, 43(2-3), AprilJune 2010, 172-194.

Tether, B., 2002. Who co-operates for innovation, and why An empirical analysis. Research Policy, 31(6), 947967.

Tracey, M., 2006. A holistic approach to new product development: new insights. Journal of Supply Chain Management, 40(4), 37-55.

Tu, Q., Vonderembse, M., Ragunathan, T., Sharkey, T.,, 2006. Absorptive capacity: Enhancing the assimilation of time-based manufacturing practices. Journal of Operations Management, 24(5), 692-710.

van Echtelt, F. E. A., Wynstra, F., van Weele, A. J., Duysters, G., 2008. Managing supplier involvement in new product development: A multiple-case study. Journal of Product Innovation Management, 25(2), $180-201$.

Van Weele, A.J., 1984. A purchasing performance measurement and evaluation. International Journal of Purchasing and Materials Management, 20(4), 16-22.

Verganti, R., 2008. Which kind of collaboration is right for you. Harvard Business Review.

Wagner, S.M., 2003. Intensity and Managerial Scope of Supplier Integration. The Journal of Supply Chain Management, 39(4), 4-15.

Wagner, S.M., Hoegl, M., 2006. Involving suppliers in product development: Insights from R\&D directors and project managers. Industrial Marketing Management, 35(8), 936-943.

Walter, A., 2003. Relationship-specific factors influencing supplier involvement in customer new product development. Journal of Business Research, 56(9), 721-733.

Ward, P.T. et al., 1998. Competitive Priorities in Operations Management. Decision Sciences, 29(4), 1035-1046. 
Wasti, S.N. and Liker, J.K., 1997. Risky Business or Competitive Power? Supplier Involvement in Japanese Product Design. Journal of Product Innovation Management 14:337-355, September.

Wognum, P., Fisscher, O.A., Weenink, S.A., 2002. Balanced relationships: management of client-supplier relationships in product development. Technovation, 22(6), 341-351.

Wong, C.Y., Boon-itt, S., Wong, C.W.Y., 2011. The contingency effects of environmental uncertainty on the relationship between supply chain integration and operational performance. Journal of Operations Management, 29(6), 604-615.

Wynstra, F., Ten Pierick, E., 2000. Managing supplier involvement in new product development: a portfolio approach. European Journal of Purchasing \& Supply Management, 6(1), 49-57.

Wynstra, F., Van Weele, A., Weggemann, M., 2001. Managing Supplier Involvement in Product Development: Three Critical Issues. European Management Journal, 19(2), 157-167.

Wynstra, F., Weele, A. Van, Axelsson, B, 1999. Purchasing involvement in product development: A framework. European Journal of Purchasing \& Supply Management 5, 129-141.

Wynstra, F., Weggeman, M., Van Weele, A., 2003. Exploring purchasing integration in product development. Industrial Marketing Management, 32(1), 69-83.

Yu, L., 2008. Collaborating With the Right Partners. MIT Sloan Management Review.

Zhao, X., Huo, B., Selen, W., Yeung, J.H.Y., 2011. The impact of internal integration and relationship commitment on external integration. Journal of Operations Management, 29(1-2), 17-32. 


\section{Appendix: Sample statistics}

\begin{tabular}{|c|c|c|c|c|c|}
\hline Descriptive & Frequency & Percentage & Descriptive & Frequency & Percentage \\
\hline Country & & & Sector & & \\
\hline Italy & 46 & 9.2 & Manufacturing & 327 & 65.7 \\
\hline Netherlands & 38 & 7.6 & Transportation, storage and communication & 29 & 5.8 \\
\hline United Kingdom & 62 & 12.4 & Wholesale and retail trade & 24 & 4.8 \\
\hline Germany & 47 & 9.4 & Construction & 23 & 4.6 \\
\hline Spain & 41 & 8.2 & Electricity, gas, and water supply & 12 & 2.4 \\
\hline Sweden & 108 & 21.7 & Professional and administrative services & 12 & 2.4 \\
\hline Finland & 30 & 6.0 & Human health and social work activities & 10 & 2.0 \\
\hline United States & 54 & 10.8 & Financial services & 9 & 1.8 \\
\hline Canada & 38 & 7.6 & Public administration and defense & 7 & 1.4 \\
\hline \multirow[t]{5}{*}{ France } & 34 & 6.8 & Agriculture, forestry, fishing, and mining & 6 & 1.2 \\
\hline & & & Hotels and restaurants & 5 & 1.0 \\
\hline & & & Arts, entertainment and recreation & 4 & 0.8 \\
\hline & & & Other & 24 & 4.8 \\
\hline & & & Missing & 6 & 1.2 \\
\hline Sales $(m \ln \epsilon)$ & & & Respondent position & & \\
\hline$<50$ & 148 & 29.7 & $\mathrm{CPO}, \mathrm{VP}$ of purchasing & 66 & 13.3 \\
\hline $51-250$ & 138 & 27.7 & Purchasing director & 113 & 22.7 \\
\hline $251-500$ & 52 & 10.4 & Purchasing manager & 225 & 45.2 \\
\hline $501-750$ & 24 & 4.8 & Senior, Project buyer & 42 & 8.4 \\
\hline $751-1000$ & 16 & 3.2 & Buyer, Purchasing agent & 24 & 4.8 \\
\hline$>1000 \mathrm{M} €$ & 94 & 18.9 & Other & 27 & 5.4 \\
\hline Missing & 26 & 5.2 & Missing & 1 & 0.2 \\
\hline Total & 498 & 100 & & 498 & 100 \\
\hline
\end{tabular}


Tables

Table 1: Selected literature on collaborative NPD

\begin{tabular}{|c|c|c|}
\hline Stream & Content & Authors \\
\hline Open and collaborative innovation & $\begin{array}{l}\text { Innovation is the outcome of a } \\
\text { collective effort rather than the } \\
\text { product of single person or firm. }\end{array}$ & $\begin{array}{l}\text { Edquist 1997; Freeman and Soete 1997; } \\
\text { Chesbrough and Crowther 2006; Parker } \\
\text { 2000; Tether } 2002\end{array}$ \\
\hline Role of suppliers in innovation & $\begin{array}{l}\text { Among the possible sources of } \\
\text { innovation outside the firm's } \\
\text { boundaries, suppliers are one of the } \\
\text { most valuable. Suppliers' engagement } \\
\text { might have different forms, such as: } \\
\text { - Supplier involvement into NPD; } \\
\text { - Supplier development; } \\
\text { - Supplier integration. }\end{array}$ & $\begin{array}{l}\text { Anderson \&Weitz 1992; Bozdogan et al. } \\
\text { 1998; Clark 1989; Dowlatshahi 1998, 1999; } \\
\text { Handfield et al. 1999; Frohlich\& Westbrook } \\
\text { 2001; Das et al. 2006; Henke \& Zhang } \\
\text { 2010; Johnsen 2009; Koufteros et al. 2007; } \\
\text { Krause \& Wagner 2008; Linder et al. 2003; } \\
\text { Nellore 2001; Petersen et al. 2003; Ragatz et } \\
\text { al. 1997; Wagner \&Hoeg1 2006; Wynstra } \\
\text { 2003; Jayaram et al. } 2010\end{array}$ \\
\hline Role of purchasing in innovation & $\begin{array}{l}\text { The purchasing department is the } \\
\text { natural interface/coordinator of the } \\
\text { supply base, therefore it must be } \\
\text { capable to take part into NPD } \\
\text { activities. }\end{array}$ & $\begin{array}{l}\text { Carr \& Pearson 2002; van Echtelt et al. } \\
\text { 2008; Lakemond et al., 2001; McGinnis \& } \\
\text { Vallopra 2001; Schiele 2010; Wagner 2003; } \\
\text { Wynstra 1999, 2000, 2003; Wynstra et al., } \\
2001\end{array}$ \\
\hline
\end{tabular}

Supplier and purchasing involvement

Role of supplier and purchasing together are understood as a strategic instrument taking effect on the

McGinnis \& Vallopra 1999a, involvement financial performance, organizational settings or production process 1999b; Carr \& Pearson 2002 improvements. 
Table 2: Correlation matrix

\begin{tabular}{|c|c|c|c|c|c|c|}
\hline Variables & 1 & 2 & 3 & 4 & 5 & 6 \\
\hline 1. Technological uncertainty & .721 & & & & & \\
\hline 2. Innovation strategy & $.424 * *$ & .854 & & & & \\
\hline 3. Supplier collaboration & $.174 \mathrm{~ns}$ & $.355 * * *$ & .775 & & & \\
\hline 4. Strategic sourcing & $.259 * *$ & $.226^{*}$ & $.424 * * *$ & .825 & & \\
\hline 5. Purchasing knowledge & $.047 \mathrm{~ns}$ & $.146 \mathrm{~ns}$ & $.362 * *$ & $.303 * *$ & .739 & \\
\hline 6. Innovation performance & $.146 \mathrm{~ns}$ & $.225 * *$ & $.426 * * *$ & $.303 * * *$ & $.260 \mathrm{~ns}$ & .676 \\
\hline
\end{tabular}

The square root of the Average Variance Extracted (AVE) is shown in bold on the diagonal. Correlations are in the lower triangle of the matrix.

The significance level of correlation is show as follows: ***p $<.001, * * \mathrm{p}<.01,{ }^{*} \mathrm{p}<.05$. 
Table 3: Results of confirmatory factor analysis

\begin{tabular}{|c|c|c|c|c|c|c|}
\hline $\begin{array}{l}\text { First-order } \\
\text { construct }\end{array}$ & Indicator & Loading & Mean & $\begin{array}{r}\text { Std } \\
\text { dev. }\end{array}$ & $\mathbf{C R}$ & AVE \\
\hline \multirow{3}{*}{$\begin{array}{l}\text { Technological } \\
\text { uncertainty }\end{array}$} & Technologies in this category are new to your firm & 0.696 & \multirow{3}{*}{2.86} & \multirow{3}{*}{0.89} & \multirow{3}{*}{0.765} & \multirow{3}{*}{0.520} \\
\hline & Technologies change in this category & 0.728 & & & & \\
\hline & Products/services are new to your firm & 0.739 & & & & \\
\hline \multirow{2}{*}{$\begin{array}{l}\text { Innovation } \\
\text { strategy }\end{array}$} & Time-to-market with suppliers & 0.715 & \multirow{2}{*}{3.47} & \multirow{2}{*}{1.16} & \multirow{2}{*}{0.840} & \multirow{2}{*}{0.729} \\
\hline & Introduction rates of new/improved products/services & 0.973 & & & & \\
\hline \multirow{3}{*}{$\begin{array}{l}\text { Supplier } \\
\text { collaboration }\end{array}$} & Supplier development & 0.725 & \multirow{3}{*}{4.02} & \multirow{3}{*}{0.88} & \multirow{3}{*}{0.818} & \multirow{3}{*}{0.601} \\
\hline & Supplier involvement into NPD & 0.851 & & & & \\
\hline & Supplier integration in order fulfilment & 0.744 & & & & \\
\hline \multirow{4}{*}{$\begin{array}{l}\text { Strategic } \\
\text { sourcing }\end{array}$} & Supply market analysis & 0.863 & \multirow{4}{*}{3.77} & \multirow{4}{*}{1.08} & \multirow{4}{*}{0.894} & \multirow{4}{*}{0.681} \\
\hline & Spend analysis & 0.861 & & & & \\
\hline & Sourcing strategy & 0.865 & & & & \\
\hline & Supplier selection and contracting & 0.699 & & & & \\
\hline \multirow{4}{*}{$\begin{array}{l}\text { Purchasing } \\
\text { knowledge }\end{array}$} & When making business decisions & 0.721 & \multirow{4}{*}{4.61} & \multirow{4}{*}{0.75} & \multirow{4}{*}{0.823} & \multirow{4}{*}{0.547} \\
\hline & When dealing with new technologies & 0.911 & & & & \\
\hline & Wen managing daily operations & 0.505 & & & & \\
\hline & When dealing with human issues & 0.763 & & & & \\
\hline \multirow{2}{*}{$\begin{array}{l}\text { Innovation } \\
\text { performance }\end{array}$} & Supplier time-to-market for new or improved prod./serv. & 0.643 & \multirow{2}{*}{4.61} & \multirow{2}{*}{1.00} & \multirow{2}{*}{0.627} & \multirow{2}{*}{0.457} \\
\hline & Level of innovation in products/service from suppliers & 0.708 & & & & \\
\hline
\end{tabular}

Fit indexes: chi-square $=146.1 ;$-value $=0.027 ;$ child.f. $=1.27 ; C F I=.992 ; R M S E A=.023$ 
Table 4: Path analysis parameter estimates

\begin{tabular}{lclccc} 
Path & & & $\begin{array}{c}\text { Standard } \\
\text { Estimate }\end{array}$ & p-value & Conclusion \\
\hline Innovation strategy & $<---$ & Technological uncertainty & .435 & $* * *$ & \\
Strategic sourcing & $<---$ & Innovation strategy & .128 & .021 & Fail to reject H1a \\
Supplier collaboration & $<---$ & Innovation strategy & .321 & $* * *$ & Fail to reject H1b \\
Supplier collaboration & $<---$ & Technological uncertainty & .044 & .476 & \\
Strategic sourcing & $<---$ & Technological uncertainty & .197 & .002 & \\
Supplier collaboration & $<---$ & Purchasing knowledge & .340 & $* * *$ & Fail to reject H2 \\
Strategic sourcing & $<---$ & Purchasing knowledge & .296 & $* * *$ & Fail to reject H3 \\
Innovation performance & $<---$ & Supplier collaboration & .336 & $* * *$ & Fail to reject H4 \\
Innovation performance & $<---$ & Strategic sourcing & .156 & .014 & Fail to reject H5 \\
\hline
\end{tabular}

Fit indexes: chi-square $=185.27 ;$-value $=0.000 ;$ chi $/$ d.f. $=1.557 ; C F I=.982 ; R M S E A=.033$ 


\section{Figures}

Figure 1: Theoretical model

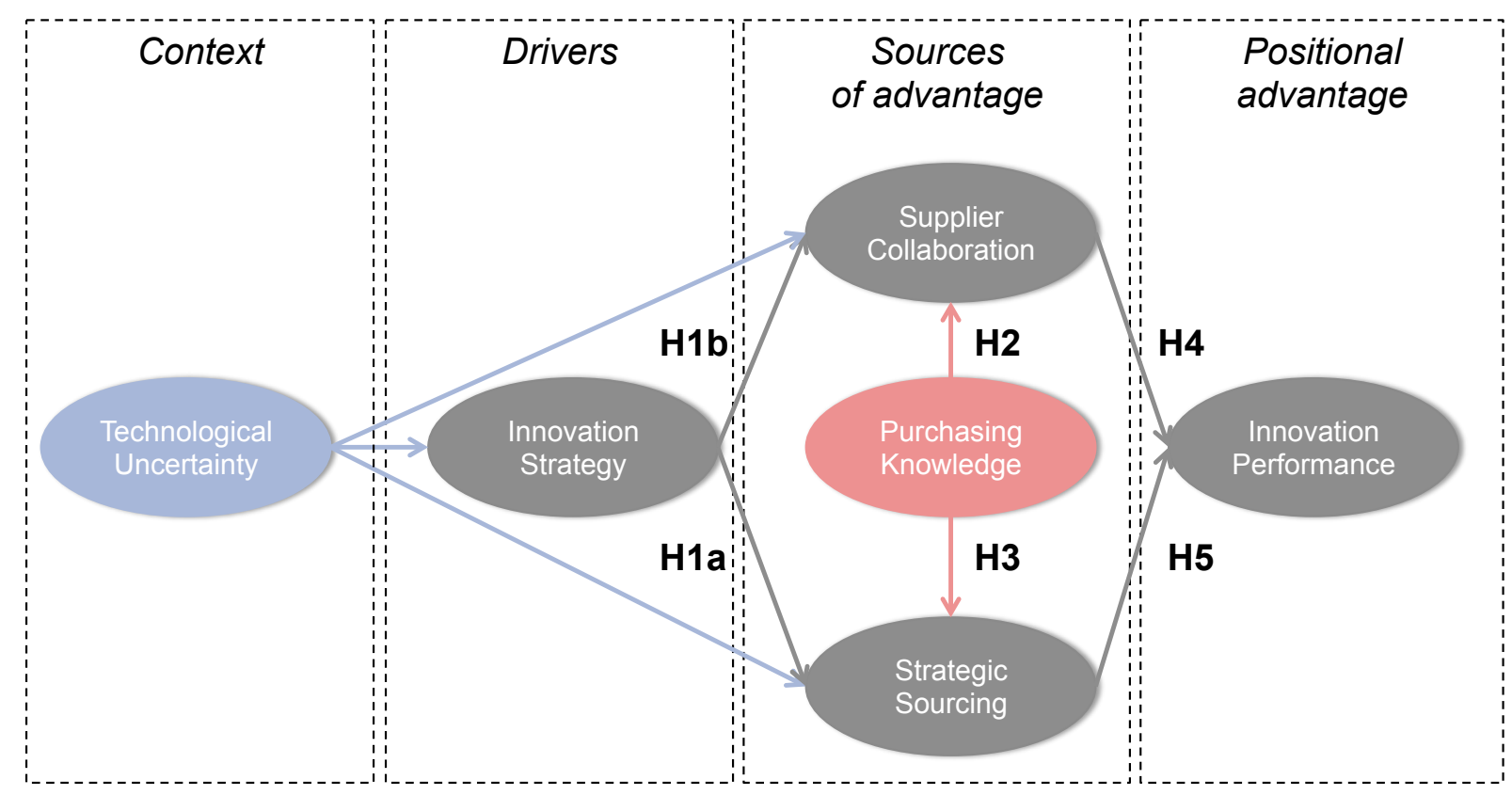

